\title{
Optimization of the criteria for cord blood unit selection for transplantation in recipients of the different age groups: current view and prospects in Ukraine
}

\author{
Nemtinov P. ${ }^{1}$, Ustymenko A. ${ }^{2,3}$, Lobyntseva G. ${ }^{1}$, Panchenko L. ${ }^{1}$, Shupyk O. ${ }^{1}$, Sokolov M. ${ }^{1}$, Salyutin R. ${ }^{1}$, Palianytsia S. ${ }^{1}$ \\ ${ }^{1}$ Coordination Center for Transplantation of Organs, Tissues and Cells of the Ministry of Health of Ukraine, Kyiv, Ukraine \\ ${ }^{2}$ State Institute of Genetic and Regenerative Medicine of the National Academy of Medical Sciences of Ukraine, Kyiv, Ukraine \\ ${ }^{3}$ D. F. Chebotarev State Institute of Gerontology of the National Academy of Medical Sciences of Ukraine, Kyiv, Ukraine \\ e-mail: nemtinov@ukr.net
}

\section{ABSTRACT}

\begin{abstract}
Umbilical cord blood has been widely used to treat both malignant and non-malignant hematological diseases for over 30 years. During this time, more than 40000 successful hematopoietic stem cells (HSCs) transplantations of umbilical cord blood have been performed. However, today in Ukraine there is no public umbilical cord blood bank established for unrelated HSCs transplantation to patients with oncohematological diseases (both children and adults). In this regard, the HSCs units must be purchased abroad or the patients are sent to foreign clinics for high-cost treatment.
\end{abstract}

The establishment of a public umbilical cord blood bank in Ukraine would help in a short time to meet the needs of patients with oncohematological diseases for donor of HSCs for unrelated transplantation and save significant funds for the treatment of patients abroad. According to the experience of the world's leading oncohematological centers, when it is impossible to find either a related or haploidentical donor or unrelated transplant in all available registries, the search continues in the registers of public cord blood banks and an umbilical cord blood unit that matches the criteria is usually found. The optimal choice of umbilical cord blood unit is crucial to maximize the likelihood of successful transplant engraftment and recipient survival after the transplantation, so the criteria for cord blood unit selection for unrelated transplantation are a bit broader than those used when matching donor-recipient pairs.

The review presents the main criteria for cord blood unit selection according to the assessment of its quality, cell dose, HLA matching for unrelated transplantation to recipients of different age groups in accordance with international guidelines developed by the National Marrow Donor Program (NMDP), Center for International Blood and Marrow Transplant Research (CIBMTR), in collaboration with the NMDP Council Advisory Group, as well as in accordance with the American Society for Transplantation and Cellular Therapy (ASTCT) and the Seventh Edition of the NetCord-FACT International Standards for Cord Blood Collection, Banking, and Release for Administration.

KEY WORDS: cord blood; unrelated transplantation of hematopoietic stem cells; oncohematological diseases

Every year, thousands of patients around the world are diagnosed with diseases that need treatment by hematopoietic stem cell (HSC) transplantation. Traditionally, their source is bone marrow (BM) or peripheral blood from a related or unrelated donor. However, according to the World Marrow Donor Association (WMDA), 10000 - 15000 patients a year cannot find a matched donor from the millions of donors included in the global database. Other patients do not have enough time to find an unrelated adult donor due to the rapid progression of the disease. In these cases, umbilical cord blood (CB) may be an alternative to bone marrow or peripheral blood HSCs transplantation. [1]. 
In 2020, 293457 children were born in Ukraine, and each newborn child is a potential donor of umbilical cord blood without any risk to his/her health and the health of his/her mother [2]. Thus, with a state program and proper organization of the process, Ukraine could store about 290000 doses of umbilical cord blood in a specialized cryobank in just one year, and in 5 years this number could be about 1500000 units. This number of $C B$ units with high content of HSCs, typed for the Major Histocompatibility Complex (MHC) antigens known as the human leukocyte antigens (HLA) in accordance with international standards and included in the State Information System for Hematopoietic Stem Cell Transplantation, could be available at any time to save citizens of Ukraine suffering from oncohematological diseases. Preservation of umbilical cord blood in a specialized (public) donor cryobank and their selection for transplantation in patients with oncohematological diseases is extremely necessary for Ukraine, as at present there are only 2609 potential donors in the Ukrainian Bone Marrow Donor Register organized by charitable foundation [3].

The establishment of a specialized public umbilical cord blood bank during the COVID-19 pandemic, when strict restrictions to free movement of people have been imposed and continue to be strictly enforced in many countries that are members of the International Bone Marrow Registry, is particularly relevant and supported by Worldwide Network for Blood \& Marrow Transplantation (WBMT), Center for International Blood and Marrow Transplant Research (CIBMTR) [4]. Whereas there is a high probability that the found donor will not be able to donate stem cells due to restrictive measures or disease. Considering the fact that since 1991 Ukraine has had a very high negative population growth from 1990 to 2020 the country's population decreased by 9823700 people, which exceeds the population of the neighboring Republic of Belarus [5] - the struggle for the life of every able-bodied citizen becomes especially relevant [2].

Umbilical cord blood has been accepted as an alternative source for HSCs transplantation for the treatment of both non-malignant and malignant hematological diseases in pediatrics and in adult patients $[6,7]$. Due to the immaturity of the immune system at birth, the number of active alloreactive T-cells in cord blood is minimal. Thus, after CB transplantation, the incidence and severity of both acute and chronic graft versus host diseases (GVHD) are much lower compared to other sources of HSCs [8], however, the recovery of the immune system is delayed and the risk of infection increases. The use of $C B$ as an allograft allows less stringent HLA donor-pair matching criteria to be applied to its donor units and expands access to transplantation to recipients for whom a matched donor cannot be found. This is especially relevant for those patients who are members of racial and ethnic minorities, whose potential donors are still underrepresented in international registries [9].

\section{THE CURRENT STATE OF CORD BLOOD BANKS AND THE USE}

\section{OF CORD BLOOD STEM CELLS IN THE WORLD}

More than 30 years have passed since the world's first transplantation of CB as a source of HSCs to a patient with Fanconi's anemia was performed by Eliane Gluckman. The results of this transplantation and subsequently developed protocols of successful cryopreservation for further use on demand, contributed to the creation of umbilical cord blood banks in the early 1990s, in particular, the field of the preservation of newborn HSCs in cryobanks $[10,11]$.

Newborn HSCs banking covers state umbilical cord blood banks that store $C B$ units for the use by unrelated recipients; private banks that keep $C B$ for further use by the donor or his first or second degree relative; hybrid banks that offer combined services [12]. Today, public and hybrid cryobanks worldwide store more than 800000 units of cryopreserved CB, HLA-typed and WMDA-registered, and more than 5 million non-HLAtyped $C B$ in private cryobanks $[13,14]$. There are 131 public $C B$ banks from 41 countries in the international register of WMDA, while none is from Ukraine. Since the first CB transplantation in 1989, more than 50000 transplantations have been performed. In 2018, about $21 \%$ of CB units were transferred for transplantation between WMDA member countries under an exchange program. In France, between 1994 and 2005, $63 \%$ of transplanted $\mathrm{CB}$ units were obtained by exchange from foreign cryobanks.

It should be noted that WMDA registry services to search for and obtain a single CB unit will cost Ukraine from 500000 to $750000 \mathrm{UAH}$, which is cheaper than the cost of obtaining a bone marrow unit or peripheral blood HSCs from this register. At the same time, in Ukraine the cost of procurement and storage of one CB unit would be ten times cheaper, as there are cryobanks in the country, in particular the Cryobank of the Institute of Cell Therapy (Kyiv), which has highly qualified staff, technology and necessary material and technical base $[15,16]$. With the adoption of the relevant state program of financing this area, a public bank of donor umbilical cord blood could work in Ukraine as well.

In the medical scientific community there is a significant interest in the study of $\mathrm{CB}$ as a therapeutic tool in the treatment of not only hematological pathology, but also for the treatment of more than 80 diseases, including congenital immunodeficiencies and certain metabolic syndromes [6]. In the mid-2000s, clinical studies began on the effectiveness of $C B$ use in patients with neurological pathology. Pilot and clinical trials involving pediatric patients with conditions such as hypoxic-ischemic encephalopathy, cerebral palsy, autism spectrum disorder and acquired hearing loss have confirmed the safety and efficacy of cryopreserved autologous and allogeneic CB [17-22]. A phase I clinical trial also confirmed the safety and appropriateness of allogeneic unrelated umbilical cord blood in adult patients with ischemic stroke [23]. To date, clinical trials are investigating the effects of the use of HSCs obtained from umbilical cord blood, in particular for immunotherapy using chimeric antigen receptors, which opens new horizons for the use of CB units [24].

Based on the potential therapeutic value, high proliferative activity, lack of ethical contradictions and reduced risk of exposure to viruses and environmental toxins on neonatal stem cells, compared with cells from adult tissues, numerous CB banks have expanded the range of tissues for cryopreservation: umbilical cord, placenta, amniotic fluid and amniotic membrane. These tissues are a rich source of multipotent mesenchymal stromal cells (MMSCs) and progenitor cells, which are effectively used in the treatment of various diseases [10]. Except for amniotic fluid, which is obtained during routine amniocentesis, the above tissues are collected non-invasively after the childbirth or usually disposed as medical waste. Cryopreservation of several perinatal tissues from the same donor is possible [25]. Such services are also provided by Ukrainian umbilical cord blood banks, such as Cryobank of the Institute of Cell Therapy [16], which actively conducts clinical trials using MMSCs of the placenta and umbilical cord for the treatment of various diseases, including ischemic cardiomyopathy, knee osteoarthritis, severe COVID-19 [26].

At the end of 2020, the population of Ukraine was 41670 812, respectively, the need for allogeneic HSCs transplantation (HSCT), taking into account European experience, may be more than 1000 such transplantations per year. However, according to the Ministry of Health of Ukraine in 2020, a total of 204 bone marrow transplantations were performed in Ukraine, only 4 of them were allogeneic, i.e. 250 times less than the potential need $[2,27]$. Maximum HLA gene compatibility is required to perform allogeneic HSCT from an unrelated donor. The distribution of HLA genotypes has racial and national characteristics [28, 29]. In Germany, the number of donors is 8 million, while the probability to find a fully matched donor for Germans is about

$70 \%$, and the probability to find a donor for a patient of another nationality in this register is much lower and, for example, for Asian residents it is only $5 \%$ [30].

In 2017, 22863 HSCTs were performed in the United States, $58.7 \%$ autologous, $18.7 \%$ related and $21.8 \%$ unrelated ones. In terms of 10 million population, this is more than 280 allogeneic transplantations per year. Out of 4972 unrelated HSCTs, 628 transplantations of unrelated CB were performed, which is $13 \%$ [31, 32]. In the Russian Federation, 28.7 thousand people are diagnosed with the tumors of lymphoid and hematopoietic tissues annually [33]. Approximately one-sixth of these patients 
require allogeneic HSCT, but only $25-30 \%$ of patients have HLA-identical sibling [34]. For the rest of the patients it is necessary to search for an unrelated donor or, in his absence, to conduct haploidentical HSCT. A total of 606 allogeneic HSCTs were performed in Russia in 2018, amounting to 41.3 per 10 million people, while in some European countries, including Italy and Germany, this number in 2018 was more than 300 allogeneic HSCTs. [35-37]. In Japan, more than 1300 recipients were transplanted with $C B$ in 2017, and the total number of $C B$ transplantations for the entire previous period up to and including 2017 reached 15544 , which is almost one third of the total number of $\mathrm{CB}$ transplantations performed worldwide. The average body weight of a Japanese people is less than that of Europeans and North Americans, and this index is a factor that influences the probability of finding a matching $C B$ unit by the ratio of the total number of nucleated cells in the unit to the recipient's body weight. As a result, the vast majority of European and North American recipients with relatively high body weight were transplanted with two CB units from different donors. Since 2005, the number of adult recipients transplanted with two $\mathrm{CB}$ units in Europe has exceeded the number transplanted with single $\mathrm{CB}$ units [36], while almost all CB transplants in Japan are single. In addition, the number of $\mathrm{CB}$ transplantations in Europe and the United States has recently declined [38]. This is not due to the results of comparative clinical studies between the effectiveness of CB and stem cell transplantation from other sources, but it is a consequence of increased medical costs directly related to the transplantation of two $\mathrm{CB}$ units and the expansion of haploidentical transplantation with cyclophosphamide prescription in post-transplantation period (Haplo-PT-Cy) [39].

According to the analysis conducted by Japanese scientists, the reason for the decrease in the number of $C B$ transplantations in recent years in North America and Europe is not due to the low efficiency of umbilical cord blood transplantation as a method, but to the relatively high body weight of patients in these regions, for whom one CB unit per kilogram of their weight is not enough $[36,38,39]$. The achievements of scientists in the field of methodological approaches to increase ex vivo a sufficient number of progenitor cells and HSCs from one CB unit give hope for the active implementation of these methods in clinical practice after the completion of all phases of ongoing clinical trials [40-45]. Given this fact, it is possible that the method of unrelated transplantation of cord blood HSCs grown ex vivo will be more widely used in Europe and North America, given its high clinical and cost-effectiveness.

Probability to find an HLA-matched donor for Ukrainian patients in the unified national registry of hematopoietic stem cell donors (which should include a registry of potential donors of bone marrow HSCs, a registry of units stored and typed by HLA antigens from public donors in public banks), may be many times higher than in many foreign registries, in which donors belong to other ethnic groups and may differ significantly in HLA antigens from the donors of Ukrainian (Slavic) population and other populations living in Ukraine. A number of authors have shown that the survival of patients whose allogeneic HSCT was performed from a donor from the national registry is higher than that of patients whose transplantation was performed from donors from foreign registries [46-48].

In accordance with global practice, umbilical cord blood is donated to the donor public bank with the informed consent of the mother on a voluntary and unpaid basis. Unlike private (family) umbilical cord blood banks, where $C B$ units are stored only for personal use on a paid basis, any citizen of Ukraine with oncohematological diseases will be able to obtain a unit from a donor bank, provided it is matched by HLA antigens.

The correct choice of CB unit is crucial for its successful engraftment and survival of the recipient after transplantation. Greater availability of high-quality $C B$ units with high cell content has contributed to improved CB transplantation outcomes in recent years [10, 28, 46, 49-51]. However, choosing the optimal umbilical cord blood unit for a particular patient can be difficult because a number of $C B$ characteristics need to be considered Each developed country has identified clear criteria for selecting a $C B$ unit as a source for unrelated HSCs transplantation. An example, for the creation of Ukrainian recommendations for the selection of the optimal
$\mathrm{CB}$ unit would be the following recommendations of the American Society for Transplantation and Cellular Therapy (ASTCT) [49], according to which certain criteria must be met when choosing a CB unit as a cell graft $[24,52-61]$

CRITERIA FOR THE MINIMUIM NUMIBER OF CELLS IN ONE UMIBILICAL CORD BLOOD UNIT FOR ITS SUCCESSFUL ENGRAFTMENT

The minimum threshold values for total nucleated cells (TNCs) and content of $\mathrm{CD} 34^{+}$hematopoietic cell for single-unit CB transplants vary by country and additional factors such as HLA overlap and which diseases, malignant or non-malignant, have become indicative of HSCT.

\section{The minimum dose of TNCs}

The minimum TNCs dose $>2.5 \cdot 10^{7} / \mathrm{kg}$ of recipient weight $[52,55$, 62 ] is used in the United States based on studies showing successful CB transplant engraftment, low transplant-related mortality, and higher survival at a cell dose higher than the specified threshold [63-65]. The United Kingdom and Europe suggest a minimum dose TNCs $>3.0 \cdot 10^{7} / \mathrm{kg}$ for a single CB transplantation [53-54, 66] based on studies that have shown that a dose of TNCs which excesses this threshold has been associated with reduced mortality $[67,68]$. Japan has adopted a lower dose threshold of TNCs $2.0 \cdot 10^{7} / \mathrm{kg}[56,69]$ to expand access to single-dose CB transplantation. This decrease in the number of cells is due to the fact that the Japanese have lower average body weight and height than citizens of the United States and Western Europe.

The use of TNCs doses that significantly exceed the accepted minimum threshold values of TNCs (from 2.0 to $3.0 \cdot 10^{7} / \mathrm{kg}$ ), promotes better engraftment of the $\mathrm{CB}$ transplant and is accompanied by lower mortality, especially with a significant difference in HLA antigens [64, 69-72]. Higher minimum TNCs thresholds (e. g. TNCs $\geq 4.0-5.0 \cdot 10^{7} / \mathrm{kg}$ ) are recommended for $\mathrm{CB}$ doses for non-malignant diseases. In non-malignancies, the relationship between the effect of TNCs dose and the level of HLA matching on graft quality and engraftment rate is less clear. This may be due to insufficient knowledge of both the nature of these disorders and how the results of previous treatment affect the results of transplantation, as well as the relative lack of data on methods and results of treatment of such patients compared to malignant hematological pathologies.

For example, patients with hemoglobinopathies before the need for transplantation of HSCs from bone marrow, peripheral or umbilical cord blood, did not receive any course of chemotherapy in the previous period of treatment, and after pre-transplant myeloablation have bone marrow with a higher cell count and less pronounced immunosuppression than patients with hematologic malignancies. At the same time, due to the large number of blood transfusions in the anamnesis, such recipients are more likely to have antibodies to HLA. Considering all the above, in nonmalignant diseases, parameters such as compliance with the cell dose per kilogram of body weight of the recipient and a high level of HLA matching are critical predictors of the result, which requires a higher cell dose than malignant diseases [53, 54, 73-78].

\section{The minimum dose of $\mathrm{CD}^{+} 4^{+}$cells}

To date, the minimum allowable threshold for the number of CD34+ cells in the CB unit has not been established yet. However, it is known that the dose of CD34+ cells is the most important factor in the restoration of hematopoiesis [56, 57, 59, 70, 79, 80-82]. However, according to some studies, there is no direct relationship between the number of transplanted CD34+cells (based on body weight) and the survival of recipients in the post-transplant period [56, 59, 70, 79].

Existing in the United States [52, 55] and updated Eurocord guidelines [24] allow a minimum dose of CD34+ cells $1.5 \cdot 10^{5} / \mathrm{kg}$ body weight of the recipient when transplanting a single CB unit. Currently, the ASTCT recommends a higher minimum dose of $\mathrm{CD} 34^{+}$cells to alleviate prolonged cytopenia after transplantation [49]. If the minimum number of cells in one CB unit is insufficient, consideration should be given to transplanting two $C B$ units from different donors, or using one of the effective methods of increasing the number of $\mathrm{CB}$ cells ex vivo, or using another cell product [24]. 
METHODS OF INCREASING THE NUMBER OF STEM CELLS IN A CB

\section{UNIT EX VIVO FOR SINGLE-DOSE TRANSPLANTATION}

The increase in the number of stem cells and progenitor cells of $\mathrm{CB}$ ex vivo in order to solve the problem of limiting the transplantation of one $C B$ unit with low content of HSCs has been studied for a long time [40-43]. A number of methodological approaches are used to achieve the quantitative quality of CB transplant [44].

Delaney et al. showed that rapid recovery of the myeloid lineage after $\mathrm{CB}$ transplantation was made possible by Notch-mediated expansion of human $\mathrm{CB}$ progenitor cells ex vivo and infusion of cord blood together with another $\mathrm{CB}$ unit from which HSCs were expanded ex vivo. Their use helped to reduce the recovery time of neutrophils by an average of 10 days compared to the transplantation of two conventional $C B$ units from different donors [45]. In addition, the efficiency of using a $\mathrm{CB}$ unit, which insufficient number of progenitor cells and HSCs was increased ex vivo and cryopreserved - the so-called "off-shelf unit", which is prepared in advance and does not require any time to cultivate HSCs for their expansion is still being studied (NCT01690520).

There is evidence that due to the use of a culture of mesenchymal stromal cells (mesoblasts) the engraftment of the CB graft is faster than in its absence [40]. Possibilities of increasing the number of progenitor cells and HSCs in a CB unit ex vivo using means of enhancing the directed migration (homing) of umbilical cord blood cells into the bone marrow are also described. In addition, there are encouraging results using direct injection of a $\mathrm{CB}$ unit into the bone marrow or co-infusion of $\mathrm{CB}$ with a haploidentical graft (BM or peripheral blood HSCs) deprived of T-cells [44].

It has been shown that the addition of nicotinamide together with cytokines that stimulate hematopoiesis in the culture of hematopoietic progenitor cells derived from the CB increases primitive CD34 ${ }^{+} \mathrm{CD} 38-$ cells, enhances their homing to the bone marrow and increases the engraftment potential of $\mathrm{CD}_{4} 4^{+}$cell cultures [83]. These properties of nicotinamide were used to develop the cell product NiCord - a product of ex vivo cultured progenitor cells and HSCs obtained from the fraction of CD133+ cord blood cells. The product is designed specifically to address the problems associated with delayed graft engraftment due to low TNCs and $\mathrm{CD} 34^{+}$cells content when transplantation to an adult with relatively large body weight is required. It should be noted that NiCord was developed as a separate graft. It differs from other cord blood products with increased ex vivo number of progenitor cells and HSCs because T-cell fraction from the thawed CB unit is pre-separated, cryopreserved and stored for the period of culturing of this unit ex vivo until the simultaneous introduction of both cell types - an increased number of progenitor cells and a cryopreserved fraction of T-cells. The use of NiCord reduces the recovery time of neutrophils, which averages 11.5 days, while the average recovery time of neutrophils after myeloablative HLA-identical allogeneic BM transplantation is 20 days, and after HLA-identical mobilized transplantation of peripheral blood HSCs it accounts for 15 days [79]. This reduction in the recovery time of blood neutrophils contributes to a significant reduction in bacterial infections in recipients during the first 100 days after transplantation compared with patients receiving HSCs from peripheral blood or BM [85-87].

The study «Evaluation of the safety and efficacy of NiCord transplantation to patients with malignant hematological pathology» showed that cell transplantation is safe and effective to reduce the time of hematopoiesis restoration; it does not require co-infusion of the second $\mathrm{CB}$ unit from another donor and provides stable hematopoiesis for more than 7 years $[88,89]$. A retrospective study of a cohort of patients receiving standard myeloablative CB transplantation showed that NiCord recipient group had a lower tendency to develop severe acute GVHD, lower recurrence-free mortality, and fewer severe relapses [88].

A lot of adult recipients require two $C B$ units to provide adequate number of HSCs and progenitor cells for reliable engraftment. Therefore, in most countries, transplantation of two CB units is introduced into clinical practice $[90,91]$. However, the addition of a second unit of $C B$ significantly increases the cost of transplantation, which is associated with delayed platelet recovery and a higher incidence of chronic GVHD [62]. NiCord, if it is demonstrated in a phase III clinical trial comparing the efficacy of a standard CB transplantation after myeloablative therapy, may eliminate the need for a second $C B$ transplantation when the cellularity of the first CB unit before the increase of its HSCs ex vivo is insufficient for a particular recipient. In addition, NiCord technology allows the use of $\mathrm{CB}$ units for adult patients that cannot otherwise be used owing to the excessive risk of graft insufficiency due to a deficiency in stem and progenitor cells.

But, despite some success and prospects for the application of the above technologies, they remain experimental and it is not yet possible to draw definitive conclusions about their reproducibility, cost-effectiveness, long-term results, so they need further study $[24,88]$.

\section{INDICATIONS FOR THE USE OF THE SECOND CB UNIT FROM ANOTH-}

\section{ER DONOR AND THE CRITERIA FOR ITS SELECTION}

For patients who lack the number of cells from one $C B$ unit, transplantation of two $C B$ units from different donors should be considered. It was found that two CB units, each of which has insufficient number of cells for single-dose transplantation, can be successfully combined into one graft $[92,93]$. Two randomized clinical trials of myeloablative therapy followed by CB transplantation in children and young adults have shown that the addition of the second unit is not beneficial if the cellularity of the first one is adequate by the above criteria. These findings suggest that transplantation of two CB units should be avoided in patients for whom a single CB unit with an adequate amount of TNCs is suitable after donor/ recipient HLA matching $[62,66]$.

However, the other two trials used different criteria for the minimum amount of TNCs, which did not take into account the dose of CD34+ cells and the matching of $8 \mathrm{HLA}$ alleles. Moreover, caution should be exercised in extrapolating these findings to adults who are more likely to receive low-intensity conditioned chemotherapy and, therefore, may benefit from a "graft-versus-leukemia" effect enhanced by transplantation of two $C B$ units $[92,93]$. The use of two $C B$ units also increases the probability that at least one of the two CB units will have optimal engraftment [49].

\section{Minimum doses of TNCs and CD34+ cells in a CB unit for the trans-}

\section{plantation of two CB units}

The doses of TNCs and CD34+ cells are important for the transplantation of two CB units [69, 94-99]. According to the guidelines of ASTCT, Eurocord, and the United Kingdom, the TNCs dose $\geq 1.5 \cdot 10^{7} / \mathrm{kg}$ body weight of the recipient and the dose of $\mathrm{CD} 34^{+}$cells $\geq 1 \cdot 10^{5} / \mathrm{kg}$ body weight of the recipient for each CB unit for two-dose transplantation are generally accepted. They were adopted as minimum thresholds to make transplantation for most patients more accessible [24, 49, 53-55]. However, a higher minimum dose of $\mathrm{CD} 34^{+}$is now recommended for each $\mathrm{CB}$ unit (Table 1) [49].

When transplanting two CB units, the cells of one of them become dominant and provide long-term hematopoiesis, but, when selecting these units, it is impossible to predict which of them will dominate [98]. Considering all the above, the characteristics of both units are equally important and the same selection criteria should be applied to each of them [49]. In the absence of a matched donor of BM or peripheral blood HSCs in the registry, and if the bank has a well-matched HLA donor but a $\mathrm{CB}$ unit with low cellularity and is unable to find an adequate pair for transplantation of two $\mathrm{CB}$ units, a combination of transplantation of this well HLA matched CB unit with low-cellularity and HSCs of peripheral blood obtained from a haploidentical donor should be considered

\section{Combined transplantation of cells from a haploidentical donor}

\section{and a unit of unrelated umbilical cord blood (Haplo-Cord)}

This approach combines the use of a smaller dose, but a qualitatively matched unrelated CB unit together with mobilized CD34+ peripheral blood cells from a haploidentical donor. In this case, early engraftment and restoration of hematopoiesis is achieved due to haploidentical donor cells, which subsequently provide the opportunity for stable and long-term engraftment of an unrelated CB unit. This approach, using both myeloablative regimens 


\begin{tabular}{|c|c|c|}
\hline STEP & ACTION & COMMENTS \\
\hline 1 & $\begin{array}{l}\text { Enter the high resolution HLA profile of } \\
\text { the patient, body weight }(\mathrm{kg}) \text { in a special } \\
\text { program for searching CB units and } \\
\text { perform sorting of suitable units. }\end{array}$ & $\begin{array}{l}2 \text { options for the initial CB units search: } \\
\text { a) to sort by a higher dose of CD } 34^{+} \text {cells or TNCs (better HLA matched units will be below the list at } \\
\text { this time); } \\
\text { b) sort by HLA (units with lower cellularity will be higher on the results page). } \\
\text { Note: sorting by } 8 \text {-allele HLA matching is based on the highest match level }\end{array}$ \\
\hline 2 & $\begin{array}{l}\text { Exclude CB units with low-dose of TNCs } \\
\text { from the search }\end{array}$ & $\begin{array}{l}\text { Minimum dose of TNCs: } \\
\text { - for the transplantation of one CB unit: } 2.5 \cdot 10^{7} / \mathrm{kg} \text {; } \\
\text { - for the transplantation of two CB units: } 1.5 \cdot 10^{7} / \mathrm{kg} \text { for each CB unit. } \\
\text { Note: The highest minimum dose for TNCs is recommended (step 9). }\end{array}$ \\
\hline 3 & $\begin{array}{l}\text { Exclude CB units with low-dose of } \\
\text { CD34 }^{+} \text {cells from the search* }\end{array}$ & $\begin{array}{l}\text { The minimum dose of } \mathrm{CD} 34^{+} \text {cells: } \\
\text { - for the transplantation of one CB unit: } 1.5 \cdot 10^{5} / \mathrm{kg} \text {; } \\
\text { - for the transplantation of two CB units: } 1.0 \cdot 10^{5} / \mathrm{kg} \text { for each } \mathrm{CB} \text { unit. } \\
\text { Note: The highest minimum dose of CD34+ cells is recommended (step 9). }\end{array}$ \\
\hline 4 & $\begin{array}{l}\text { Exclude from the search the units that } \\
\text { have a low level of HLA matching }\end{array}$ & $\begin{array}{l}\text { Matching of at least } 6 \text { loci (antigen-level typing for HLA-A, -B, allele-level typing for -DRB1): } \\
\text { - choice of CB units by at least } 4 \text { loci out of } 6 \text {; } \\
\text { - } \quad \text { chatching of at least } 8 \text { alleles (HLA-A, -B, -C, -DRB1); } \\
\text { by least } 4 \text { loci out of } 8 .\end{array}$ \\
\hline 5 & Exclude old CB units from the search & $\begin{array}{l}\text { Units saved } 15 \text { or more years ago are excluded from the search. } \\
\text { Note: If necessary, old units can be included in the search. }\end{array}$ \\
\hline 6 & $\begin{array}{l}\text { Exclude from the search units with non- } \\
\text { standard volume of cryopreservation } \\
\text { media and/or with a high content of } \\
\text { erythrocytes }\end{array}$ & $\begin{array}{l}\text { Optimal CB unit volume: } 24-28 \mathrm{~mL} \text { ( } 1 \mathrm{bag} \text { ) or } 48-54 \mathrm{~mL} \text { ( } 2 \text { bags of } 24-28 \mathrm{~mL} \text { each) } \\
\text { Note: } \\
\text { - If the unit volume is } 30 \mathrm{~mL} \text {, make sure that it is free of erythrocytes (programmatically filter such } \\
\text { a sample if erythrocytes are present in large quantities). } \\
\text { - Rarely, unit volumes are counted without } \sim 5 \mathrm{~mL} \text { of DMSO (19 to } 21 \mathrm{~mL} \text { ). If so, check the correct } \\
\text { cryopreservation medium volume. }\end{array}$ \\
\hline 7 & $\begin{array}{l}\text { Exclude from the search units from CB } \\
\text { banks that are not FACT accredited }\end{array}$ & $\begin{array}{l}\text { Priority is given to banks with FACT accreditation to optimize the quality of samples. } \\
\text { Note: The possibility of avoiding cooperation with some banks (for example, banks unknown to the } \\
\text { transplant center) is being considered. }\end{array}$ \\
\hline 9 & $\begin{array}{l}\text { Revise and select CB units for } \\
\text { confirmatory typing by HLA. } \\
\text { It is desirable that the software product } \\
\text { for the selection of a donor-recipient } \\
\text { pair allows you to store and keep in a } \\
\text { specially created folder for a particular } \\
\text { recipient data on selected CB units. } \\
\text { In this folder it is necessary to save and } \\
\text { reserve compared and selected CB units } \\
\text { until the final decision on the use of a } \\
\text { particular CB unit (so that at the same } \\
\text { time these pre-selected units could not } \\
\text { be reserved for another recipient, in } \\
\text { case a transplant coordinator performs } \\
\text { the search for a unit with a similar } \\
\text { genotype in the other transplantation } \\
\text { center). } \\
\text { Transplantation will require 1-2 basic CB } \\
\text { units and 1-2 reserved ones. }\end{array}$ & 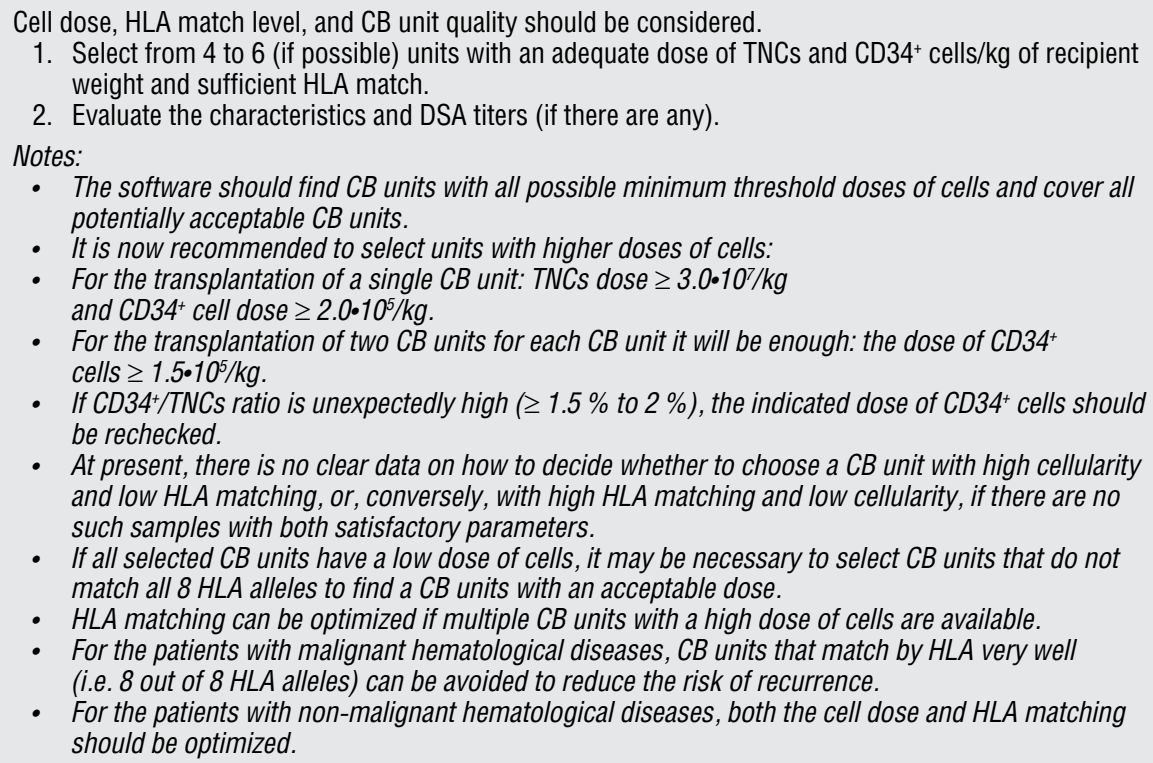 \\
\hline
\end{tabular}

Notes: * - CB units with an adequate dose of CD34+ cells, but which do not meet the criteria for the minimum dose of TNCs, can be considered as candidates for transplantation if the ratio of CD34+/TNCS is in the acceptable range. For such CB units it is necessary to take into account the accreditation of the CB bank, the quality of processing and the year of cryopreservation. 
Table 1. Possible step-by-step algorithm for finding a cord blood unit for implementation in specialized software for finding a donorrecipient pair in the State Information System of Hematopoietic Stem Cell Transplantation and in the «Ukrainian Register of Bone Marrow Donors» based on the recommendations of the American Society for Transplantation and Cellular Therapy (ASTCT) [38].

and low-intensity conditioning regimens, has shown a reduction in infectious and immunological complications. In addition, it may be useful for adults with a limited number of unrelated donors and the presence of matching unrelated $C B$ units with low cellularity, but with an available haploidentical donor, which allows to use of a single unrelated $C B$ unit [100-102].

Due to the improvement of the methods of maintenance immunosuppressive therapy in the post-transplant period, the method of haploidentical transplantation has become widespread. We will present below the data from clinical studies comparing the effects on two-year survival of recipients after haploidentical transplantation and CB transplantation.

When comparing the results of clinical trials using unrelated $C B$ and BM from HLA-haploidentical relatives, no statistically significant difference was found between the effects of sources of donors on two-year survival without disease progression (NCT01597778). The authors concluded that both sources of donors are expanding patients' access to transplantation under the low-intensity conditioning protocol. At the same time, analysis of secondary endpoints, including overall survival, favors haploidentical BM donors for adult recipients [103].

Duihong Li et al. (2020) after a retrospective analysis of the results of the treatment of 102 children and 1311 adults who underwent CB transplantation and 94 children and 915 adults who underwent haploidentical transplantation of BM or peripheral blood HSCs, found that the number of cases of chronic graft-versus-host reactions and disease-free survival for two years did not differ significantly. Two years later, there was no difference in the number of relapses, recurrence-free survival and disease-free survival. The authors concluded that both $\mathrm{CB}$ transplantation and haploidentical BM or peripheral blood HSCs transplantation are equivalent effective treatments for adult patients for whom an HLA-matched bone marrow donor or peripheral blood HSCs were not found [104].

\section{EVALUATION OF DONOR/RECIPIENT PAIR MATCHING BY HLA}

Eurocord criteria for umbilical cord blood sampling are more stringent and require:

- High resolution HLA typing of recipients and CB units by HLA-A, $-B,-C$ and $-D R B 1$;

- To avoid CB units with more than two HLA mismatches and avoid HLA-C mismatches;

- Transplanting two CB units, it is not necessary to perform HLA matching between units.

According to Eurocord, the dose of cells in the CB unit(s) should correspond to the body weight of the recipient; HLA matching should be performed depending on the indications before transplantation:

1. In non-malignant diseases, the dose of cells should be increased (> 5.0.107 TNCs $/ \mathrm{kg}$ ) and the best HLA matching found. If the criterion of the minimum number of cells in one $\mathrm{CB}$ unit is not reached, it is necessary to consider transplantation of two $\mathrm{CB}$ units for non-malignant diseases as well.

2. For patients with high body weight, a CB unit should first be selected according to the criteria of the number of cells, and then - according to the level of HLA matching.

Whenever possible, recipients should be screened for antibodies to HLA. CB units against which recipients have donor-specific antibodies (DSA) should be avoided. This is especially true for recipients with malignancies due to the risk of rejection. CB units from FACT or FDA-accredited umbilical cord blood banks should be preferred. It is mandatory to select a $\mathrm{CB}$ unit with satellite tubes for matching the donor-recipient pair.
If there are several $\mathrm{CB}$ units that simultaneously meet the above Eurocord criteria, the best one is selected according to the following parameters:

1. Matching by $A B O$ system.

2. Taking the absence of NIMA (non-inherited maternal antigen) and KIR (killer cell immunoglobulin-like receptor); it should be noted that there are insufficient data to select units based on NIMA or KIR-L (KIR ligand) status.

3. CB units with a high content of erythrocytes should be avoided, or used only if there are no units deprived of erythrocytes.

4. The volume of the cryopreserved unit should be considered if further dilution is required after thawing.

5. It is desirable to choose units that were cryopreserved lately, as they are more likely to be stored according to the optimal protocols of $C B$ banks.

If the minimum number of cells in one $C B$ unit is insufficient, consideration should be given to transplanting two units, as well as inviting the patient to participate in a clinical trial examining the use of a $\mathrm{CB}$ unit with increased ex vivo stem cell number or adding another cell product to a $\mathrm{CB}$ unit, such as CD34+ haploidentical donor cells [24, 100-102].

RECOMIIENDATIONS FOR HLA TYPING FOR PATIENTS AND ADULT DONORS IN ACCORDANCE WITH THE NATIONAL MARROW DONOR PROGRAM (NMDP) AND THE GUIDELINES OF THE CENTER FOR INTERNATIONAL BLOOD AND MARROW TRANSPLANT RESEARCH

\section{(CIBMTR)}

The analysis of scientific and clinical data has shown that determining the antigen recognition domain (ARD) for classical HLA loci reduces mortality and morbidity after transplantation. Therefore, NMDP specia-lists have developed and posted on a specialized Internet resource (http://hla.alleles.org) HLA nomenclature, which allows not only to match the donor-recipient pair by high resolution HLA, but also to take into account alleles that encode the same amino acid sequence in ARD $[105,106]$.

This nomenclature based on DNA analysis methods has four numeric fields (for example, $A^{\star} 02: 01: 01: 01$ ). Allele typing, also called high-resolution typing or 2-field typing [106], distinguishes between HLA genes encoding cell surface proteins that differ in the amino acid sequence of the ARD [107]. ARD is an active part of the HLA molecule that binds peptide antigens and interacts with T lymphocytes and natural receptors of killer cells [109].

Other designations that indicate $A R D$ identity include $G(A * 02: 01: 01 G$ indicating nucleotide sequence identity in the ARD exons) and $P$ ( $A^{\star} 02: 01 P$ indicating protein sequence identity in the ARD) nomenclatures. Both $G$ and $P$ groups of alleles can also be represented as multiple allele codes that are provided and offered to consider by the NMDP. A description of the alleles included in a specific code can be found at https://hml.nmdp.org/MacUl.

For comparison, there are the requirements for the level of HLA matching for donors of BM or peripheral blood HSCs (according to the recommendations of the NMDP) before transplantation. Thus, patients and donors should be typed by high-resolution DNA genotyping for HLA-A, HLA-B, HLA-C, HLA-DRB1 and HLA-DPB1 loci [52]. Other loci (e.g., HLA-DQB1, HLA-DRB3/4/5, HLA-DQA1, and HLA-DPA1) have not been shown to have significant effects on survival alone; however, their identification may help to develop an effective transplant-finding strategy among several similar donors for a recipient sensitized to HLA to avoid the potential risk of graft rejection [110,111].

\section{NMDP RECOMIMENDATIONS FOR HLA TYPING FOR CB UNITS}

$C B$ units should be typed by high-resolution DNA genotyping for HLAA, HLA-B, HLA-C and HLA-DRB1 [55]. The donor-recipient pair matching software developed by NMDP performs it in high resolution and takes into account DQB1 and DPB1 [49].

DETERMINATION OF A CB UNIT FOR THE SELECTION OF A DONORRECIPIENT PAIR ACCORDING TO THE RECOMMENDATIONS OF THE ASTCT (2020):

- $\quad$ preliminary assessment is performed by 6 HLA loci (antigenlevel typing for HLA-A, HLA-B; allele-level typing for HLA-DRB1); 
- complete comparison is performed by 8 HLA loci (allele-level typing for HLA-A, -B, -C, -DRB1) [38].

MINIIMAL REQUIRED HLA MATCHING IN THE DONOR/RECIPIENT PAIR HLA matching by 6 loci: antigen-level typing for HLA-A, HLA-B, allele-level typing for HLA-DRB1

The CB unit/recipient HLA matching is based on antigen-level typing for HLA-A, -B typing, while in most countries HLA-DRB1 is recommended allele-level typing (HLA matching by 6 loci) [55, 112], except for Japan, which considers it sufficient to determine all 6 of the above loci by antigen-level typing, not allele [113]. The minimum matching requirement of 4 out of the 6 loci has been widely recognized when comparing the donor-recipient pair for HLA [24, 52, 53-55, 62, 63, 112, 113].

At $C B$ transplantation in the case of malignant hematological diseases, HLA mismatching is associated with poor engraftment, as well as an increased risk of GVHD and post-transplant mortality [56, 57, 113, 114-116]. Whereas, the above mentioned mismatch reduces the risk of recurrence $[56,113,114,116]$. Low levels of matching by 6 HLA loci were associated with poorer post-transplant survival in one group of $C B$ transplantation studies $[30,57,63,116]$, but were not detected in other studies $[65,70,113,114,117,118]$. According to some authors, the negative impact of HLA mismatch on post-transplant survival is limited to children [69].

HLA matching by allele-level typing for HLA-A, HLA-B, HLA-C, HLADRB1 (matching by 8 out of 8 HLA alleles)

Currently in Europe [24], Great Britain [53] and the USA [52, 62] it is necessary to perform allele-level typing at least 8 loci of HLA-A, -B, -C, -DRB1 (8-allele level of HLA matching). In malignancies, a higher mismatch of CB unit by 8 alleles of HLA was associated with poorer engraftment, an increased incidence of acute GVHD, and an increase in post-transplant mortality, but with a lower recurrence rate $[67,70,119]$. The deterioration of survival was observed only when matching less than 4 alleles out of 8 by HLA $[42,67]$, or less than 5 alleles out of 8 by HLA in children [70]. It is recommended to avoid $C B$ units that match less than 4 out of the $8 \mathrm{HLA}$ alleles [52, 55], if possible.

HLA matching of two CB units from different donors, if transplantation of one unit is not possible

To date, the recommendations for the minimum match of 6 HLA loci for each of the two $\mathrm{CB}$ units are the same as for the transplantation of only one unit, as it is never known which of the two transplanted units will be dominant in the recipient's body. A number of clinical studies have not shown either harmful effects or the benefit of matching of higher than by 6 out of the $8 \mathrm{HLA}$ alleles on the survival rate after the transplantation of two CB units [99, 120-122]. Therefore, the requirement for minimal donor/recipient pair matching by 8 out of the $8 \mathrm{HLA}$ alleles (8/8) is not clearly established for the transplantation of two CB units. There is no need to perform HLA matching of one $\mathrm{CB}$ unit with another during two-dose transplantation [123].

\section{CORD BLOOD TRANSPLANTATION FOR NON-MALIGNANT HEMATO-}

\section{LOGICAL DISEASES}

During cord blood transplantation for non-malignant diseases, it is recommended to use $\mathrm{CB}$ units with maximum matching by HLA alleles, as this affects the best results of post-transplant survival [124-126]. There is no convincing evidence that matching by 10 or 12 alleles has a better effect on the final result of transplantation [56, 67, 68, 71, 127-132]. It does not make sense to detect non-inherited maternal antigens or inherited paternal antigens (IPA) in most patients [49, 133-136].

\section{PECULIARITIES OF THE FORMATION OF THE POTENTIAL BM AND PERIPHERAL BLOOD HSCS DONOR BASE}

A retrospective analysis of the NMDP found that almost $50 \%$ of registered donors were unavailable due to inability to contact them or the changes in their personal circumstances [143]. In addition, the level of donor availability varies and depends on which of the international registries they are in.
In this regard, there is a need to form a new interaction with BM and peripheral blood HSCs donors entered in the register, namely: to include in the donor's information letter the date of last contact with him and the date of reaffirmation of the desire to be a donor to help transplant centers make donor choice more likely. It is important that centers find multiple adult donors or suitable CB units, given the likelihood of the donor's health deteriorating, which could significantly affect the timeliness of the donation. While storing $C B$ in a cryobank makes it possible to get it when needed as quickly as possible.

\section{THE INFLUENCE OF RACE/ETHNICITY ON THE PROCESS OF FINDING}

\section{A MIATCHED DONOR-RECIPIENT PAIR}

The level of availability (likelihood of matching) of BM and peripheral blood HSCs donors very often depends on what race and/or ethnic group they belong to. These circumstances are especially important for ethnically diverse groups, particularly in multinational Ukraine. By filling up a Ukrainian public cord blood bank, it will be much easier to store up $C B$ units from small ethnic groups after carrying out appropriate explanatory work with women in labor.

HLA alleles and haplotypes are distributed with varying frequency among different racial/ethnic groups $[9,138,139]$. Low-frequency HLA alleles are more common in the general population in individual haplotypes, as well as in other HLA alleles from the ancestral racial/ethnic group shared between the recipient and the donor. The NMDP HapLogic ${ }^{\mathrm{TM}}$ donor-recipient matching algorithm takes race and ethnicity into account when predicting the probability of a high-resolution match, so centers should try to accurately obtain and enter this patient data for search [52].

\section{CORD BLOOD UNIT QUALITY ASSESSIMENT ACCORDING TO NMDP} AND ASTCT RECOMIMENDATIONS

The quality of a CB unit is determined by the standard operating procedures for sample preparation, approved by the cord blood bank, and it is influenced by the methods of processing and cryopreservation. The purpose of the evaluation is to select high quality CB units with the maximum number of living cells after thawing, which subsequently affects engraftment. For this purpose, it is necessary to adhere to certain norms, which is possible under the condition of standardization of cord blood storage in appropriate cryostorage of accredited and licensed banks.

Standardization of cord blood processing and cryopreservation methods in specialized banks is crucial to ensure consistent quality of $C B$ units and reliability of test results before and after thawing [60]. Accordingly, $C B$ units from banks accredited by the Foundation for the Accreditation of Cellular Therapy (FACT) should be given priority in selection $[55,117]$.

In the United States, a license from the Food and Drug Administration (FDA) confirms the high quality of $\mathrm{CB}$ units. FDA regulations ensure the safety, identity, engraftment potential and purity of the product, and ensure that all stages from collection to release of the CB unit are rigorously monitored and the results meet predetermined standards. $C B$ units from banks that have not passed FACT or FDA licensing procedure, but were prepared in accordance with the recommendations of these structures, are also acceptable for use [124].

\section{The volume of a cryopreserved $C B$ unit}

Most automated systems for cord blood processing provide a standardized final volume of cell suspension (approximately $25 \mathrm{~mL}$ with dimethyl sulfoxide solution or $50 \mathrm{~mL}$ in two $25 \mathrm{~mL}$ collection bags). There are non-standard volumes of cryopreservation medium that are associated with lower viability after thawing - such specimens have a lower engraftment potential $[60,140]$. In CB units with unusually large volumes, a large number of erythrocytes are very common. Their use is not recommended due to the high probability of serious post-transfusion reactions $[124,141]$.

It has been proven that thawed cryopreserved $C B$ units after many years in liquid nitrogen retain good cell survival and the potential for transplant engraftment $[60,142-144]$. However, most centers take the age of $\mathrm{CB}$ units into account when selecting, as banking practices have 
improved over time and units collected over the last 10-15 years have been tested and stored according to more optimized protocols than those previously collected.

\section{The viability potential of a CB unit after thawing}

According to NetCord-FACT, the minimum viability of thawed $\mathrm{CD} 34^{+}$ hematopoietic cells unit should be $\geq 70 \%$. However, at other conditions being equal, preference for transplantation is given to $C B$ units with a higher minimum viability of $\mathrm{CD} 34^{+}$cells $\geq 80 \%$ according to flow cytometry. If possible, units with less cell viability should be avoided.

\section{Other quality indicators of a $C B$ unit}

After receiving a $C B$ unit for transplantation from any cryobank immediately prior to transplantation, it should be verified by confirmatory HLA typing (or similar analysis using DNA diagnostic methods) of the accompanying satellite tube. The suitability of the samples is based on the assessment of possible risk factors in the mother and the screening of markers of her infectious diseases. CB units from donors that do not meet certain criteria can be used based on the FDA's requirements to Urgent Medical Need. The potential risk of refusing to use a particular $C B$ unit should be weighed against the potential benefit of its transplantation to other $C B$ units or treatment options.

\section{THE USE OF CB UNITS AGAINST WHICH THE RECIPIENT}

\section{HAS DONOR-SPECIFIC ANTI-HLA ANTIBODIES ACCORDING}

TO THE RECOMIMENDATIONS OF THE ASTCT (2020)

The effect of DSA on the engraftment of a CB unit after transplantation in patients with hematological malignancies is controversial. However, there are data to look out for $[54,145-148]$, as some $[149,150]$ but not all studies show that the presence of DSA increases the risk of graft rejection:

- DSA titer, specificity to a particular locus and their ability to bind complement, as well as the dose of transplanted cells should be considered in each case [151,152].

- $\quad$ Additional important factors include diagnosis and prior immunosuppressive therapy of the recipient and the planned intensity of conditioning, as they also affect the potential for graft rejection.

- $\quad$ Taking into account the presence of DSA should not significantly affect the choice of a CB unit, if such a unit has a sufficient number of cells.

- The algorithm for reducing the number of antibodies is not standardized, so it does not guarantee transplant engraftment.

- In CB transplantation, recipients with non-malignant diseases should avoid units against which DSA have been found [49].

\section{FACTORS THAT SHOULD NOT BE CONSIDERED WHEN CHOOSING}

\section{A CB UNIT}

According to the recommendations of the ASTCT (2020), in contrast to the guidelines of Eurocord (2019), when choosing a unit of umbilical cord blood we should not take into account:

- Matching by ABO system. Mismatch by ABO system has not been established as a determinant of reduced survival in $\mathrm{CB}$ transplantation [152-156].

- $\quad \mathrm{KIR}$ typing. The importance of typing immunoglobulin-like receptors (KIRs) in cells remains uncertain, so it may not be taken into account when selecting units [157-162].

- The presence of nucleated erythrocytes in the sample, sex or origin of the donor.

\section{POSSIBLE STEPS FOR CHOOSING A CORD BLOOD UNIT}

The step-by-step algorithm for finding a CB unit shown in Table 1 can be integrated into the State Information System of Hematopoietic Stem Cell Transplantation (during its creation or as a modernization) and in the «Ukrainian Register of Bone Marrow Donors» [49]. Transplantation centers have the right to modify the selection stages according to their experience and specific needs. At present, there is no clear understanding what the priority is, a cell dose or HLA match level, for the choice of a CB unit for transplantation. While some studies have evaluated the relative importance of the TNCs dose and the presence of a match between 4 and 6 out of 6 HLA alleles $[110,117]$, there are insufficient data on the relative importance of the CD34+ ${ }^{+}$cell dose versus the 8-allele HLA match [70].

When selecting from multiple CB units, the first ones should be selected the units with the optimal cell dose and/or HLA match, and only as a last resort with the minimum acceptable values.

Among recipients (most children and some adults with common haplotypes) who nave multiple suitable $\mathrm{CB}$ units with high cell doses (e.g., TNCs $\geq 3.0 \cdot 10^{7} / \mathrm{kg}$ and $\mathrm{CD} 34^{+} \geq 2.0 \cdot 10^{5} / \mathrm{kg}$ ), better compatibility by HLA can be identified as a priority. Conversely, for most adults and some older children, selection of a CB unit(s) by cell dose may have a priority over HLA matching selection, and transplantation of two CB units may be required. For recipients for whom it is difficult to find a $C B$ unit, the priority is given to selection for an adequate dose of cells, even when this unit has a low level of HLA matching.

Recipients with hematological malignancies, other things being equal, should avoid transplanting CB units with a high level of HLA matching (matching 8 out of $8 \mathrm{HLA}$ alleles) due to an increased risk of underlying disease relapse $[70,119]$. At the same time, in patients with non-malignant diseases, a high level of HLA matching is very important for successful transplant engraftment [125].

Threshold doses of TNCs and CD $34^{+}$cells should be considered and CB units used where appropriate doses exceed the minimum for each threshold to minimize the risk of graft failure and to avoid prolonged post-transplant cytopenia.

Considering all the above, the choice of a CB unit for a successful transplantation leaves a lot of unresolved issues, which are currently difficult to unambiguously answer to. The importance of one or another criterion for the selection of a quality $\mathrm{CB}$ unit is determined taking into account many factors that cover a wide range of indicators of both the donor (we are talking about the mother) and the recipient.

The most common questions concern the options for the selection of units by certain parameters, namely: the priority of selection by cell dose or level of HLA matching; in which case to use one CB unit for transplantation, and in which - two. The question of safe transplantation of $C B$ units with a low initial dose of cells, but with a high level of HLA matching remains open.

Thus, since the frequency and severity of acute GVHD after cord blood transplantation is much lower than in the case of BM or peripheral blood HSCs transplantation [8], this allows less stringent criteria to be applied to HLA donor-recipient pairs for CB units sampling and expands access to transplantation for patients for whom it is not possible to find a matched donor of bone marrow HSCs or peripheral blood. This is especially true for those recipients who are representatives of racial and ethnic minorities, potential donors of which are still underrepresented in international registers [9]. 


\section{CONCLUSION}

The presented data can be used in the development of national guidelines for the use of donor cord blood in patients of different ages with malignant and non-malignant hematological diseases, as well as in the development of software based on donor-recipient matching algorithms for the national registry of bone marrow and umbilical cord blood. It also can be taken into account when creating a national public (donor) umbilical cord blood bank.

\section{REFERENCES:}

1. Available: https://wmda.info/cord-blood/basics-cord-blood/

2. Available: http://www.ukrstat.gov.ua/

3. Available: https://ubmdr.org/

4. Algwaiz G, et al. Guideline: Real-World Issues and Potential Solutions in Hematopoietic Cell Transplantation during the COVID-19 Pandemic: Perspectives from the Worldwide Network for Blood and Marrow Transplantation and Center for International Blood and Marrow Transplant Research Health Services and International Studies Committee. Biol Blood Marrow Transplant. 2020; 26:2181-2189. D0I:10.1016/j.bbmt.2020.07.021.

5. Available: https://www.belstat.gov.by/

6. Cairo MS, Kindwall-Keller TL. Indications for Utilization of Stored Umbilical Cord Blood. 2018. Available online: https://www.cb-association.org/indications-forutilization-of-stored-umbilical-cord-blood.

7. Smith AR, Wagner JE. Alternative haematopoietic stem cell sources for transplantation: place of umbilical cord blood. Br J Haematol. 2009 ; 147(2):246-261.

8. Rocha V, Wagner JE Jr, Sobocinski KA, et al. Eurocord and International Bone Marrow Transplant Registry Working Committee on Alternative Donor and Stem Cell Sources. Graft-versus-host disease in children who have received a cord-blood or bone marrow transplant from an HLAidentical sibling. N Engl J Med. 2000; 342(25):1846-1854

9. Gragert L, Eapen M, Williams E, et al. HLA match likelihoods for hematopoietic stem-cell grafts in the U.S. registry. N Engl J Med. 2014 ; 371(4):339-348.

10. Brown KS, Rao MS, Brown HL. The Future State of Newborn Stem Cell Banking. J Clin Med. 2019; 8(1):117. D0I:10.3390/jcm8010117.

11. Ballen KK, Verter F, Kurtzberg J. Umbilical cord blood donation: Public or private? Bone Marrow Transpl. 2015; 50:1271-1278.

12. Dessels C, Alessandrini M, Pepper MS. Factors Influencing the Umbilical Cord Blood Stem Cell Industry: An Evolving Treatment Landscape. Stem Cells TransI Med. 2018; 7:643-650.

13. Kurtzberg J. A History of Cord Blood Banking and Transplantation. Stem Cells Transl Med. 2017; 6:1309-1311.

14. Ballen K. Update on umbilical cord blood transplantation. F1000Research. 2017; 6: 1556.

15. Jöris $M$, et al. Worldwide survey on key indicators for public cord blood banking technologies: By the World Marrow Donor Association Cord Blood Working Group Stem Cells. Transl Med. 2021; 10(2):222-229. DOI:10.1002/sctm.20-0246.

16. Available: https://cryobank.ua/

17. Baumgartner LS; Moore E; Shook D, Messina S, Day MC, Green J Nandy, et al. Safety of Autologous Umbilical Cord Blood Therapy for Acquired Sensorineural Hearing Loss in Children. J Audiol Otol. 2018; 22:209-222.

18. Dawson G, Sun J, Davlantis KS, Murias M, Franz L, Troy J, et al. Autologous Cord Blood Infusions Are Safe and Feasible in Young Children with Autism Spectrum Disorder: Results of a Single-Center Phase I Open-Label Trial. Stem Cells Transl. Med. 2017; 6:1332-1339.

19. Sun JM, Song AW, Case LE, Mikati MA, Gustafson KE, Simmons R, et al. Effect of Autologous Cord Blood Infusion on Motor Function and Brain Connectivity in Young Children with Cerebral Palsy: A Randomized, Placebo-Controlled Trial. Stem Cells Transl Med. 2017; 6:2071-2078.

20. Chez M, Lepage C, Parise C, Dang-Chu A, Hankins A, Carroll M. Safety and Observations from a Placebo-Controlled, Crossover Study to Assess Use of Autologous Umbilical Cord Blood Stem Cells to Improve Symptoms in Children with Autism. Stem Cells Transl Med. 2018; 7:333-341.

21. Sun J, Allison J, McLaughlin C, Sledge L, Waters-Pick B, Wease $S$, et al. Differences in quality between privately and publicly banked umbilical cord blood units: A pilot study of autologous cord blood infusion in children with acquired neurologic disorders. Transfusion. 2010; 50:1980-1987.

22. Lengel D, et al. Stem Cell Therapy for Pediatric Traumatic Brain Injury. Front Neurol. 2020; 11:601286. D0I:10.3389/fneur.2020.601286.

23. Laskowitz DT, Bennett ER, Durham RJ, Volpi JJ, Wiese JR, Frankel M, et al. Allogeneic Umbilical Cord Blood Infusion for Adults with Ischemic Stroke: Clinical Outcomes from a Phase 1 Safety Study. Stem Cells Transl Med. 2018; 7:521-529.

24. Ruggeri A. Optimizing cord blood selection. Hematology. 2019; 1:522-531.

25. Skiles ML, Brown KS, TatzW, Swingle K, Brown HL. Quantitative analysis of composite umbilical cord tissue health using a standardized explant approach and an assay of metabolic activity. Cytotherapy. 2018; 20:564-575.

26. Available: https://csict.com.ua/rnd/about/research/

27. Available: https://moz.gov.ua/article/news/maksim-stepanov-pidpisav-memorandum-z-ukrainskim-reestrom-donoriv-kistkovogo-mozku-ta-idonor.

28. Alyansky AL, Makarenko OA, Ivanova NE, et al. Razvitie registra nerodstvennykh donorov kostnogo mozga v Rossiyskoy Federatsii: opyt NII detskoy onkologii, gematologii i transplantologii im. R. M. Gorbachevoy [Development of the register of unrelated bone marrow donors in the Russian Federation: the experience of the Research Institute of Pediatric Oncology, Hematology and Transplantology named after R. M. Gorbacheva]. Rossiyskiy zhurnal detskoy gematologii i onkologii - Russian Journal of Pediatric Hematology and Oncology. 2016; 3(2):68-74. DOI: 10.17650/2311-1267-2016-3-2-68-74. [In Russian]

29. Hamaganova EG, Kuzminova EP, Abdrakhimova AR, et al. Geneticheskie distantsii po HLA-genam mezhdu donorami gemopoeticheskikh stvolovykh kletok registra FGBU «NMITs gematologii» Minzdrava Rossii i drugimi rossiyskimi i mirovymi populyatsiyami [Genetic distances by HLA genes between donors of hematopoietic stem cells of the register of the Federal State Budgetary Institution «National Medical Research Center of Hematology» of the Ministry of Health of Russia and other Russian and world populations]. Transfuziologiya - Transfusiology. 2018; 19(1):13-26. [In Russian]

30. Müller CR, Ehninger G, Goldmann SF. Gene and haplotype frequencies for the loci HLA-A, HLA-B, and HLA-DR based on over 13,000 German blood donors. Hum Immunol. 2003; 64(1):137-51. DOI: 10.1016/S0198-8859(02)00706-1. 
31. Center for International Blood and Marrow Transplant Research / Transplant Activity Report Covering 2013-2017 / Table 14. Number of HCTs performed in the United States and reported to CIBMTR - donor type and cell source by year 2013-2017. https://bloodstemcell.hrsa.gov/sites/default/files/bloodstemcell/data/ transplant-activity/transplants-year-donor-type-cell-source.pdf

32. Available: https://www.who.int/countries/usa/ru/

33. Oksenoit GK, Nikitina SYu, Ageeva LI, et al. Zdravookhranenie v Rossii 2017 [Healthcare in Russia 2017] Stat. sb./Rosstat - stat. coll./Rosstat collection. Moscow, 2017. 170 p. [In Russian]

34. Rosenmayr A, Pointner-Prager M, Mitterschiffthaler A, et al. What are a patient's current chances of finding a matched unrelated donor? Twenty years' central search experience in a small country. Bone Marrow Transplant. 2012; 47(2):172-80. D0I: 10.1038/bmt.2011.67.

35. Mendeleeva LP, Savchenko VG, Parovichnikova EN, et al. Analiz transplantatsionnoy aktivnosti v RF za 2018 god (otchet mezhregional'nogo registra) [Analysis of transplantation activity in the Russian Federation in 2018 (the interregional register report)]. Gematologiya i transfuziologiya - Hematology and Transfusiology. 2020; 65(1):180. [In Russian]

36. Passweg JR, Baldomero H, Bader $P$, et al. Is the use of unrelated donor transplantation leveling off in Europe? The 2016 European Society for Blood and Marrow Transplant activity survey report. Bone Marrow Transplant. 2018; 53(9):1139-48. D0l:10.1038/s41409-018-0153-1.

37. Available: https://showdata.gks.ru/report/278928/

38. Niederwieser D, Baldomero H, Szer J, Gratwohl M, Aljurf M, Atsuta Y, et al. Hematopoietic stem cell transplantation activity worldwide in 2012 and a SWOT analysis of the Worldwide Network for Blood and Marrow Transplantation Group including the global survey. Bone Marrow Transplant. 2016 ; 51(6):778-85.

39. Yamamoto $H$. Single cord blood transplantation in Japan; expanding the possibilities of CBT. International Journal of Hematology. 2019; 110:39-49. Available: DOI:10.1007/s12185-019-02672-4.

40. de Lima M, McNiece I, Robinson SN, et al. Cord-blood engraftment with ex vivo mesenchymal-cell coculture. N Engl J Med. 2012; 367:2305-2315.

41. Wagner JEJr, Brunstein CG, Boitano AE, et al. Phase I/II trial of stemregenin-1 expanded umbilical cord blood hematopoietic stem cells supports testing as a standalone graft. Cell Stem Cell. 2016; 18:144-155.

42. Fares I, Chagraoui J, Gareau Y, et al. Cord blood expansion. Pyrimidoindole derivatives are agonists of human hematopoietic stem cell self-renewal. Science. 2014; 345:1509-1512.

43. Stiff PJ, Montesinos P, Peled T, et al. Cohort-controlled comparison of umbilical cord blood transplantation using carlecortemcel-L, a single progenitor-enriched cord blood, to double cord blood unit transplantation. Biol Blood Marrow Transplant. 2018; 24:1463-1470.

44. Baron F, Ruggeri A, Nagler A. Methods of ex vivo expansion of human cord blood cells: challenges, successes and clinical implications. Expert Rev Hematol. 2016; 9(3):297-314.

45. Delaney C, Heimfeld S, Brashem-Stein C, Voorhies H, Manger RL, Bernstein ID. Notch-mediated expansion of human cord blood progenitor cells capable of rapid myeloid reconstitution. Nat Med. 2010; 16(2):232-236.

46. Vasilyeva VA, Kuzmina LA, Parovichnikova EN, Drokov MYu, Dmitrova AA, Starikova OS, et al. Vypolnenie transplantatsiy allogennykh gemopoeticheskikh stvolovykh kletok ot nerodstvennykh donorov iz Rossiyskogo i zarubezhnogo registrov v odnom transplantatsionnom tsentre [The allogeneic hematopoietic stem cells transplantation from unrelated donors from the Russian and foreign registries in the same transplant center]. Gematologiya i transfuziologiya - Hematology and transfusiology. 2020; 65(3):299-311. D0I:10.35754/0234-5730-2020-65-3-299-311. [In Russian]

47. Furst D, Muller C, Vucinic V, et al. High-resolution HLA matching in hematopoietic stem cell transplantation: a retrospective collaborative analysis. Blood. 2013; 122(18):3220-9. DOI:10.1182/blood-2013-02-482547.

48. Morishima $Y$, Kawase T, Malkki M, et al. Signifi cance of ethnicity in the risk of acute graft-versus-Host disease and leukemia relapse after unrelated donor hematopoietic stem cell transplantation. Biol Blood Marrow Transplant. 2013; 19(8):1197-203. DOI: 10.1016/j.bbmt.2013.05.020.

49. Politikos I, et al. Guidelines for Cord Blood Unit Selection. Practice quidelines. TCT. 2020; 26(12):2190-2196. D0I:10.1016/j.bbmt.2020.07.030.

50. Ballen KK, Gluckman E, Broxmeyer HE. Umbilical cord blood transplantation: the first 25 years and beyond. Blood. 2013; 122(4):491-498.

51. Pasquini MC, et al. Worldwide Network for Blood and Marrow Transplantation Recommendations for Establishing a Hematopoietic Cell Transplantation Program, Part I: Minimum Requirements and Beyond. Biology of Blood and Marrow Transplantation 2019; 25:2322-2329. D0l:10.1016/j.bbmt.2019.05.002.

52. Dehn J, et al. Selection of unrelated donors and cord blood units for hematopoietic cell transplantation: guidelines from the NMDP/CIBMTR. Blood. 2019; 134(12):924-934; D0I:10.1182/blood.2019001212.

53. Hough R, Danby R, Russell N, et al. Recommendations for a standard UK approach to incorporating umbilical cord blood into clinical transplantation practice: an update on cord blood unit selection, donor selection algorithms and conditioning protocols. Br J Haematol. 2016; 172:360-370.

54. Ruggeri A, Paviglianiti A, Gluckman E, Rocha V. Impact of HLA in cord blood transplantation outcomes. HLA. 2016; 87:413-421.

55. Barker JN, Kurtzberg J, Ballen K, et al. Optimal practices in unrelated donor cord blood transplantation for hematologic malignancies. Biol Blood Marrow Transplant. 2017; 23:882-896.

56. Yanada $M$, Konuma $T$, Kuwatsuka $Y$, et al. Unit selection for umbilical cord blood transplantation for adults with acute myeloid leukemia in complete remission: a Japanese experience. Bone MarrowTransplant. 2019; 54:1789-1798.

57. Wagner JE, Barker JN, DeFor TE, et al. Transplantation of unrelated donor umbilical cord blood in 102 patients with malignant and nonmalignant diseases: influence of CD34 cell dose and HLA disparity on treatmentrelated mortality and survival. Blood. 2002; 100:1611-1618.

58. Terakura $S$, Azuma $E$, Murata $M$, et al. Hematopoietic engraftment in recipients of unrelated donor umbilical cord blood is affected by the CD34+ and CD8 ${ }^{+}$cell doses. Biol Blood Marrow Transplant. 2007; 13:822-830.

59. Konuma T, Kato S, Oiwa-Monna M, et al. Cryopreserved CD34(+) cell dose, but not total nucleated cell dose, influences hematopoietic recovery and extensive chronic graft-versus-host disease after single-unit cord blood transplantation in adult patients. Biol Blood Marrow Transplant. 2017; 23:1142-1150.

60. Purtill D, Smith K, Devlin S, et al. Dominant unit CD34+ cell dose predicts engraftment after double-unit cord blood transplantation and is influenced by bank practice. Blood. 2014; 124:2905-2912.

61. Lemarie C, Esterni B, Calmels B, et al. CD34(+) progenitors are reproducibly recovered in thawed umbilical grafts, and positively influence haematopoietic reconstitution after transplantation. Bone Marrow Transplant. 2007; 39:453-460.

62. Wagner Jr JE, Eapen M, Carter S, et al. One-unit versus two-unit cordblood transplantation for hematologic cancers. N Engl J Med. 2014 ; 371:1685-1694.

63. Rubinstein P, Carrier C, Scaradavou A, et al. Outcomes among 562 recipients of placental-blood transplants from unrelated donors. N Engl J Med. 1998; 339:15651577.

64. Kurtzberg J, Prasad VK, Carter SL, et al. Results of the Cord Blood Transplantation Study (COBLT): clinical outcomes of unrelated donor umbilical cord blood transplantation in pediatric patients with hematologic malignancies. Blood. 2008; 112:4318-4327.

65. Cohen YC, Scaradavou A, Stevens $C E$, et al. Factors affecting mortality following myeloablative cord blood transplantation in adults: a pooled analysis of three international registries. Bone Marrow Transplant. 2011; 46:70-76. 
66. Michel G, Galambrun C, Sirvent $A$, et al. Single- vs double-unit cord blood transplantation for children and young adults with acute leukemia or myelodysplastic syndrome. Blood. 2016; 127:3450-3457.

67. Eapen M, Klein JP, Ruggeri A, et al. Impact of allele-level HLA matching on outcomes after myeloablative single unit umbilical cord blood transplantation for hematologic malignancy. Blood. 2014; 123:133-140.

68. Eapen M, Klein JP, Sanz GF, et al. Effect of donor-recipient HLA matching at HLA A, B, C, and DRB1 on outcomes after umbilical-cord blood transplantation for leukaemia and myelodysplastic syndrome: a retrospective analysis. Lancet Oncol. 2011; 12:1214-1221.

69. Atsuta $Y$, Kanda J, Takanashi $M$, et al. Different effects of HLA disparity on transplant outcomes after single-unit cord blood transplantation between pediatric and adult patients with leukemia. Haematologica. 2013; 98:814-822.

70. Yokoyama H, Morishima Y, Fuji S, et al. Impact of HLA allele mismatch at HLA-A, -B, -C, and -DRB1 in single cord blood transplantation. Biol Blood Marrow Transplant. 2020; 26:519-528.

71. Barker JN, Scaradavou A, Stevens CE. Combined effect of total nucleated cell dose and HLA match on transplantation outcome in 1061 cord blood recipients with hematologic malignancies. Blood. 2010; 115:1843-1849.

72. Ballen KK, Logan BR, Laughlin MJ, et al. Effect of cord blood processing on transplantation outcomes after single myeloablative umbilical cord blood transplantation. Biol Blood Marrow Transplant. 2015; 21:688-695.

73. Gluckman E, Rocha V, lonescu I, et al. Results of unrelated cord blood transplant in Fanconi anemia patients: risk factor analysis for engraftment and survival. Biol Blood Marrow Transplant. 2007; 13:1073-1082.

74. Peffault de Latour $R$, Chevret $S$, Jubert $C$, et al. Unrelated cord blood transplantation in patients with idiopathic refractory severe aplastic anemia: a nationwide phase 2 study. Blood. 2018; 132:750-754.

75. Peffault de Latour $R$, Purtill $D$, Ruggeri $A$, et al. Influence of nucleated cell dose on overall survival of unrelated cord blood transplantation for patients with severe acquired aplastic anemia: a study by Eurocord and the Aplastic Anemia Working Party of the European Group for Blood and Marrow Transplantation. Biol Blood Marrow Transplant. 2011; 17:78-85.

76. Gluckman E, Rocha V. Donor selection for unrelated cord blood transplants. Curr Opin Immunol. 2006; 18:565-570.

77. Fernandes JF, Rocha V, Labopin M, et al. Transplantation in patients with SCID: mismatched related stem cells or unrelated cord blood. Blood. 2012; 119:29492955.

78. Boelens $J J$, Aldenhoven M, Purtill D, et al. Outcomes of transplantation using various hematopoietic cell sources in children with Hurler syndrome after myeloablative conditioning. Blood. 2013; 121:3981-3987.

79. Nakasone H, Tabuchi K, Uchida N, et al. Which is more important for the selection of cord blood units for haematopoietic cell transplantation: the number of CD34positive cells or total nucleated cells. Br J Haematol. 2019; 185:166-169.

80. Sanz J, Sanz MA, Saavedra S, et al. Cord blood transplantation from unrelated donors in adults with high-risk acute myeloid leukemia. Biol Blood Marrow Transplant. 2010; 16:86-94.

81. Page KM, Zhang L, Mendizabal A, et al. Total colony-forming units are a strong, independent predictor of neutrophil and platelet engraftment after unrelated umbilical cord blood transplantation: a single-center analysis of 435 cord blood transplants. Biol BloodMarrow Transplant. 2011; 17:1362-1374.

82. Laughlin MJ, Barker J, Bambach B, et al. Hematopoietic engraftment and survival in adult recipients of umbilical-cord blood from unrelated donors. $\mathrm{N}$ Engl J Med. 2001; 344:1815-1822.

83. Peled T, Shoham H, Aschengrau D, et al. Nicotinamide, a SIRT1 inhibitor, inhibits differentiation and facilitates expansion of hematopoietic progenitor cells with enhanced bone marrow homing and engraftment. Exp Hematol. 2012; 40: 342-355.

84. Anasetti C, Logan BR, Lee SJ, et al. Peripheral-blood stem cells versus bone marrow from unrelated donors. N Engl J Med. 2012; 367:1487-1496.

85. Solomon SR, Sizemore CA, Sanacore $M$, et al. Total body irradiation-based myeloablative haploidentical stem cell transplantation is a safe and effective alternative to unrelated donor transplantation in patients without matched sibling donors. Biol Blood Marrow Transplant. 2015; 21:1299-1307.

86. Mielcarek M, Furlong T, O'Donnell PV, et al. Posttransplantation cyclophosphamide for prevention of graft-versus-host disease after HLA-matched mobilized blood cell transplantation. Blood. 2016; 127:1502-1508.

87. Anand S, Thomas $S$, Hyslop T, et al. Transplantation of ex vivo expanded umbilical cord blood (NiCord) decreases early infection and hospitalization. Biol Blood Marrow Transplant. 2017; 23:1151-1157.

88. Horwitz ME, Wease $S$, Blackwell B, et al. Phase I/ll study of stem-cell transplantation using a single cord blood unit expanded ex vivo with nicotinamide. J Clin Oncol. 2019; 37(5):367-374. DOI:10.1200/JC0.18.00053.

89. Horwitz ME, Chao NJ, Rizzieri DA, et al. Umbilical cord blood expansion with nicotinamide provides Iong-term multilineage engraftment. J Clin Invest. 2014; 124:3121-3128.

90. Barker JN, Weisdorf DJ, DeFor TE, et al. Transplantation of 2 partially HLA-matched umbilical cord blood units to enhance engraftment in adults with hematologic malignancy. Blood. 2005; 105:1343-1347.

91. Barker JN, Fei M, Karanes $C$, et al. Results of a prospective multicentre myeloablative double-unit cord blood transplantation trial in adult patients with acute leukaemia and myelodysplasia. Br J Haematol. 2015; 168:405-412.

92. Verneris MR, Brunstein CG, Barker J, et al. Relapse risk after umbilical cord blood transplantation: enhanced graft-versus-leukemia effect in recipients of 2 units. Blood. 2009; 114:4293-4299.

93. Balligand $L$, Galambrun $C$, Sirvent $A$, et al. Single-unit versus double-unit umbilical cord blood transplantation in children and young adults with residual leukemic disease. Biol Blood Marrow Transplant. 2019; 25:734-742.

94. Avery S, Shi W, Lubin M, et al. Influence of infused cell dose and HLA match on engraftment after double-unit cord blood allografts. Blood. $2011 ; 117: 3277-3285$.

95. Purtill $D$, Stevens $C E$, Lubin $M$, et al. Association between nondominant unit total nucleated cell dose and engraftment in myeloablative doubleunit cord blood transplantation. Biol Blood Marrow Transplant. 2015; 21:1981-1984.

96. Bejanyan N, Rogosheske J, DeFor T, et al. Higher dose of mycophenolate mofetil reduces acute graft-versus-host disease in reduced-intensity conditioning double umbilical cord blood transplantation. Biol Blood Marrow Transplant. 2015; 21:926-933.

97. Brunstein CG, Petersdorf EW, DeFor TE, et al. Impact of allele-level HLA mismatch on outcomes in recipients of double umbilical cord blood transplantation. Biol Blood Marrow Transplant. 2016; 22:487-492.

98. Tozatto-Maio K, Giannotti F, Labopin M, et al. Cord blood unit dominance analysis and effect of the winning unit on outcomes after double-unit umbilical cord blood transplantation in adults with acute leukemia: a retrospective study on behalf of Eurocord, the Cord Blood Committee of Cellular Therapy, Immunobiology Working Party, and the Acute Leukemia Working Party of the European Group for Blood and Marrow Transplantation. Biol Blood Marrow Transplant. 2018 ; 24:1657-1663.

99. Haspel RL, Kao G, Yeap BY, et al. Preinfusion variables predict the predominant unit in the setting of reduced-intensity double cord blood transplantation. Bone Marrow Transplant. 2008; 41:523-529. 
100. Gupta AO, Wagner JE. Umbilical Cord Blood Transplants: Current Status and Evolving Therapies. Front Pediatr. 2020; 8:570282. D0I:10.3389/fped.2020.570282.

101. Liu H, Rich ES, Godley L, Odenike O, Joseph L, Marino S, et al. Reduced-intensity conditioning with combined haploidentical and cord blood transplantation results in rapid engraftment, low GVHD, and durable remissions. Blood. 2011; 118:6438-45. DOl:10.1182/blood-2011-08-372508.

102. Hsu J, Artz A, Mayer SA, Guarner D, Bishop MR, Reich-Slotky R, et al. Combined haploidentical and umbilical cord blood allogeneic stem cell transplantation for high-risk lymphoma and chronic lymphoblastic leukemia. Biol Blood Marrow Transplant. 2018; 24:359-65. D0l:10.1016/j.bbmt.2017.10.040.

103. Ephraim J. Fuchs, et al. Double unrelated umbilical cord blood vs HLA-haploidentical bone marrow transplantation: the BMT CTN 1101 trial. Blood. 2021; 137(3):420-428.

104. Duihong Li, Xiaofan Li, Lianming Liao, Nainong Li. Unrelated cord blood transplantation versus haploidentical transplantation in adult and pediatric patients with hematological malignancies -A meta-analysis and systematic review. Am J Blood Res. 2020;10(1):1-10.

105. Marsh SG, Albert ED, Bodmer WF, et al. Nomenclature for factors of the HLA system, 2010. Tissue Antigens. 2010; 75(4):291-455.

106. Robinson J, Halliwell JA, Hayhurst JD, Flicek P, ParhamP, Marsh SG. The IPD and IMGT/HLA database: allele variant databases. Nucleic Acids Res. 2015; 43:D423-D431.

107. European Federation for Immunogenetics. Standards for Histocompatibility \& Immunogenetics Testing. 2019.Version 7. Available at:https://www.efi-web.org/ news/version-7-ofthe-standards-for-histocompatibilityimmunogentics-testing.html.

108. Nunes E, Heslop H, Fernandez-Vina M, et al. Definitions of histocompatibility typing terms. Blood. 2011; 118(23):e180-e183.

109. Hou L, Vierra-Green C, Lazaro A, et al. Limited HLA sequence variation outside of antigen recognition domain exons of 36010 of 10 matched unrelated hematopoietic stem cell transplant donor-recipient pairs. HLA. 2017; 89(1):39-46.

110. Spellman S, Bray R, Rosen-Bronson S, et al. The detection of donor-directed, HLAspecific alloantibodies in recipients of unrelated hematopoietic cell transplantation is predictive of graft failure. Blood. 2010; 115(13):2704-2708.

111. Ciurea SO, Thall PF, Wang $X$, et al. Donorspecific anti-HLA Abs and graft failure in matched unrelated donor hematopoietic stem cell transplantation. Blood. 2011; 118(22): 5957-5964.

112. Barker JN, Byam C, Scaradavou A. How I treat: the selection and acquisition of unrelated cord blood grafts. Blood. 2011; 117:2332-2339.

113. Yanada $M$, Konuma $T$, Kuwatsuka $Y$, et al. Unit selection for umbilical cord blood transplantation for adults with acute myeloid leukemia in complete remission: a Japanese experience. Bone Marrow Transplant. 2019; 54:1789-1798.

114. Gluckman E, Rocha V, Arcese W, et al. Factors associated with outcomes of unrelated cord blood transplant: guidelines for donor choice. Exp Hematol. 2004; 32:397-407.

115. Kanda J., Hayashi H., Ruggeri A., et al. Prognostic factors for adult single cord blood transplantation among European and Japanese populations: the Eurocord/ ALWP-EBMT and JSHCT/JDCHCT collaborative study. Leukemia. 2020. 34. P. 128-137.

116. Politikos I, Mazis CM, Naputo KA, et al. Analysis of the CD34+ cell to total nucleated cell content ratio of 619 transplanted and back-up cord blood units. Bone Marrow Transplant. 2020; DOl:10.1038/s41409-020-01042-7.

117. Eapen $M$, Rubinstein $P$, Zhang MJ, et al. Outcomes of transplantation of unrelated donor umbilical cord blood and bone marrow in children with acute leukaemia: a comparison study. Lancet. 2007; 369:1947-1954.

118. Scaradavou A, et al. Guidelines for Cord Blood Unit Thaw and Infusion / Biol Blood Marrow Transplant. 2020; 26:1780-1783.

119. Sanz J, Jaramillo FJ, Planelles D, et al. Impact on outcomes of human leukocyte antigen matching by allele-level typing in adults with acute myeloid leukemia undergoing umbilical cord blood transplantation. Biol Blood Marrow Transplant. 2014; 20:106-110.

120. Ponce DM, Hilden P, Devlin SM, et al. High disease-free survival with enhanced protection against relapse after double-unit cord blood transplantation when compared with T cell-depleted unrelated donor transplantation in patients with acute leukemia and chronic myelogenous leukemia. Biol Blood Marrow Transplant. 2015; 21:1985-1993.

121. Oran B, Cao K, Saliba RM, et al. Better allele-level matching improves transplant-related mortality after double cord blood transplantation. Haematologica. 2015; 100:1361-1370.

122. Delaney M, Cutler CS, Haspel RL, et al. High-resolution HLA matching in double-umbilical-cord-blood reduced-intensity transplantation in adults. Transfusion. 2009; 49:995-1002.

123. Brunstein C, Zhang MJ, Barker J, et al. The effect of inter-unit HLA matching in double umbilical cord blood transplantation for acute leukemia. Haematologica. 2017; 102:941-947.

124. Ballen $K$, Logan BR, Chitphakdithai $P$, et al. Unlicensed umbilical cord blood units provide a safe and effective graft source for a diverse population: a study of 2456 umbilical cord blood recipients. Biol Blood Marrow Transplant. 2020; 26:745-757.

125. Eapen $M$, Wang $T$, Veys $P A$, et al. Allele-level HLA matching for umbilical cord blood transplantation for non-malignant diseases in children: a retrospective analysis. Lancet Haematol. 2017; 4:e325-e333.

126. Mallhi KK, Smith AR, DeFor TE, Lund TC, Orchard PJ, Miller WP. Allele-level HLA matching impacts key outcomes following umbilical cord blood transplantation for inherited metabolic disorders. Biol Blood Marrow Transplant. 2017; 23:119-125.

127. Konuma $T$, Kato $S$, Ishii $H$, et al. HLA-DRB1 mismatch is associated with a decreased relapse in adult acute myeloid leukemia after single-unit myeloablative cord blood transplantation. Ann Hematol. 2015; 94:1233-1235.

128. Brunstein CG, Cutler CS, DeFor TE, et al. Matching at human leukocyte antigen-C improved the outcomes after double umbilical cord blood transplantation for recipients of two to four of six human leukocyte antigen-matched grafts. Biol Blood Marrow Transplant. 2017; 23:126-133.

129. Yabe T, Azuma $F$, Kashiwase $K$, et al. HLA-DPB1 mismatch induces a graftversus-leukemia effect without severe acute GVHD after single-unit umbilical cord blood transplantation. Leukemia. 2018; 32:168-175.

130. Matsuno N, Wake A, Uchida N, et al. Impact of HLA disparity in the graftversus-host direction on engraftment in adult patients receiving reducedintensity cord blood transplantation. Blood. 2009; 114:1689-1695.

131. Cunha R, Loiseau $P$, Ruggeri $A$, et al. Impact of HLA mismatch direction on outcomes after umbilical cord blood transplantation for hematological malignant disorders: a retrospective Eurocord-EBMT analysis. Bone Marrow Transplant. 2014; 49:24-29.

132. Kanda J, Atsuta $Y$, Wake A, et al. Impact of the direction of HLA mismatch on transplantation outcomes in single unrelated cord blood transplantation. Biol Blood Marrow Transplant. 2013; 19:247-254.

133. Rocha V, Spellman S, Zhang MJ, et al. Effect of HLA-matching recipients to donor noninherited maternal antigens on outcomes after mismatched umbilical cord blood transplantation for hematologic malignancy. Biol Blood Marrow Transplant. 2012; 18:1890-1896.

134. Van der Zanden HG, Van Rood JJ, Oudshoorn M, et al. Noninherited maternal antigens identify acceptable HLA mismatches: benefit to patients and costeffectiveness for cord blood banks. Biol Blood Marrow Transplant. 2014; 20:1791-1795. 
135. van Rood JJ, Scaradavou A, Stevens CE. Indirect evidence that maternal microchimerism in cord blood mediates a graft-versus-leukemia effect in cord blood transplantation. Proc Natl Acad Sci U S A. 2012; 109:2509-2514.

136. van Rood JJ, Stevens CE, Smits J, Carrier C, Carpenter C, Scaradavou A. Reexposure of cord blood to noninherited maternal HLA antigens improves transplant outcome in hematological malignancies. Proc Natl Acad Sci U S A. 2009; 106:19952-19957.

137. Switzer GE, Bruce JG, Myaskovsky L, et al. Race and ethnicity in decisions about unrelated hematopoietic stem cell donation. Blood. 2013; 121(8):1469-1476.

138. Paunic' V, Gragert L, Schneider J, Müller C, Maiers M. Charting improvements in US registry HLA typing ambiguity using a typing resolution score. Hum Immunol. 2016; 77(7):542-549.

139. Gaudieri S, Leelayuwat C, Tay GK, Townend DC, Dawkins RL. The major histocompatibility complex (MHC) contains conserved polymorphic genomic sequences that are shuffled by recombination to form ethnic-specific haplotypes. J Mol Evol. 1997; 45(1):17-23.

140. Scaradavou A, Smith KM, Hawke $R$, et al. Cord blood units with low CD34+ cell viability have a low probability of engraftment after double unit transplantation. Biol Blood Marrow Transplant. 2010; 16:500-508.

141. Barker JN, Scaradavou A. Response: the controversy of red blood cellreplete cord blood units. Blood. 2011; 118(2):480.

142. Jaing TH, Chen SH, Wen YC, Chang TY, Yang YC, Tsay PK. Effects of cryopreservation duration on the outcome of single-unit cord blood transplantation. Cell Transplant. 2018; 27:515-519.

143. Nikiforow S, Li S, Snow K, et al. Lack of impact of umbilical cord blood unit processing techniques on clinical outcomes in adult double cord blood transplant recipients. Cytotherapy. 2017; 19:272-284.

144. Mitchell R, Wagner JE, Brunstein CG, et al. Impact of long-term cryopreservation on single umbilical cord blood transplantation outcomes. Biol Blood Marrow Transplant. 2015; 21:50-54.

145. Takanashi M, Atsuta Y, Fujiwara K, et al. The impact of anti-HLA antibodies on unrelated cord blood transplantations. Blood. 2010; 116:2839-2846.

146. Takanashi M, Fujiwara K, Tanaka H, Satake M, Nakajima K. The impact of HLA antibodies on engraftment of unrelated cord blood transplants. Transfusion. 2008; 48:791-793.

147. Cutler C, Kim HT, Sun L, et al. Donor-specific anti-HLA antibodies predict outcome in double umbilical cord blood transplantation. Blood. 2011; 118:6691-6697.

148. Yamamoto $H$, Uchida $N$, Matsuno $N$, et al. Anti-HLA antibodies other than against HLA-A, -B, -DRB1 adversely affect engraftment and nonrelapse mortality in HLAmismatched single cord blood transplantation: possible implications of unrecognized donor-specific antibodies. Biol Blood Marrow Transplant. 2014; 20:16341640.

149. Brunstein CG, Noreen H, DeFor TE, Maurer D, Miller JS, Wagner JE. Anti-HLA antibodies in double umbilical cord blood transplantation. Biol Blood Marrow Transplant. 2011; 17:1704-1708.

150. Dahi PB, Barone J, Devlin SM, et al. Sustained donor engraftment in recipients of double-unit cord blood transplantation is possible despite donor-specific human leukoctye antigen antibodies. Biol Blood Marrow Transplant. 2014; 20:735-739.

151. Ciurea SO, Cao K, Fernandez-Vina M, et al. The European Society for Blood and Marrow Transplantation (EBMT) consensus guidelines for the detection and treatment of donor-specific anti-HLA antibodies (DSA) in haploidentical hematopoietic cell transplantation. Bone Marrow Transplant. 2018; 53:521-534.

152. Gladstone DE, Bettinotti MP. HLA donor-specific antibodies in allogeneic hematopoietic stem cell transplantation: challenges and opportunities. Hematology Am Soc Hematol Educ Program. 2017; 2017:645-650.

153. Wada S, Asano-Mori Y, Yamamoto $\mathrm{H}$, et al. No post-transplant pure red cell aplasia development in 106 major ABO incompatible cord blood transplantation. Bone Marrow Transplant. 2019; 54:765-768.

154. Kudek MR, Shanley R, Zantek ND, McKenna DH, Smith AR, Miller WP. Impact of graft-recipient ABO compatibility on outcomes after umbilical cord blood transplant for nonmalignant disease. Biol Blood Marrow Transplant. 2016; 22:2019-2024.

155. Konuma $T$, Kato $S$, Ooi J, et al. Effect of ABO blood group incompatibility on the outcome of single-unit cord blood transplantation after myeloablative conditioning. Biol Blood Marrow Transplant. 2014; 20:577-581.

156. Romee R, Weisdorf DJ, Brunstein C, et al. Impact of ABO-mismatch on risk of GVHD after umbilical cord blood transplantation. Bone Marrow Transplant. 2013; 48:1046-1049.

157. Brunstein CG, Wagner JE, Weisdorf DJ, et al. Negative effect of KIR alloreactivity in recipients of umbilical cord blood transplant depends on transplantation conditioning intensity. Blood. 2009; 113:5628-5634.

158. Tanaka J, Morishima Y, Takahashi Y, et al. Effects of KIR ligand incompatibility on clinical outcomes of umbilical cord blood transplantation without ATG for acute leukemia in complete remission. Blood Cancer J. 2013; 3:e164.

159. Tarek N, Gallagher MM, Chou JF, et al. KIR and HLA genotypes have no identifiable role in single-unit dominance following double-unit umbilical cord blood transplantation. Bone Marrow Transplant. 2015; 50:150-152.

160. Rettman $P$, Malard F, Legrand $N$, et al. Impact of KIR/HLA genetic combinations on double umbilical cord blood transplantation outcomes: results of a French multicentric retrospective study on behalf of the Societe Francophone de Greffe de Moelle et de Therapie Cellulaire (SFGM-TC) and the Societe Francophone d'Histocompatibilite et d'Immunogenetique (SFHI). Bone Marrow Transplant. 2016; 51:1499-1503.

161. Sekine T, Marin D, Cao K, et al. Specific combinations of donor and recipient KIR-HLA genotypes predict for large differences in outcome after cord blood transplantation. Blood. 2016; 128:297-312.

162. Rocha $V$, Ruggeri A, Spellman $S$, et al. Killer cell immunoglobulin-like receptor-ligand matching and outcomes after unrelated cord blood transplantation in acute myeloid leukemia. Biol Blood Marrow Transplant. 2016; 22:1284-1289.

163. Dehn J, Setterholm M, Buck K, Kempenich J, Gragert L, Madbouly A, et al. HapLogic: A Predictive Human Leukocyte Antigen-Matching Algorithm to Enhance Rapid Identification of the Optimal Unrelated Hematopoietic Stem Cell Sources for Transplantation Biol Blood Marrow Transplant. 2016; 22(11):2038-2046. DOI: 10.1016/j.bbmt.2016.07.022

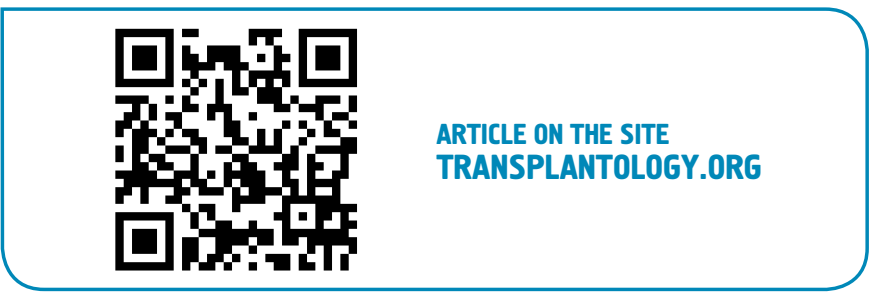

The authors declared no potential conflicts of interest with respect to the research, authorship, and/or publication of this article. 